\title{
a
}

Letter to the editor (Forensic Psychiatry)

\section{Mechanical vs. Medical Restraint in Psychiatric Complaint Cases}

\author{
Søren Birkeland
}

Syddansk Universitet, Odense, Denmark

sbirkeland@health.sdu.dk

Psychiatric coercive measures (CM) like mechanical restraints (MR; e.g., belt and strap fixation) are used in many countries [1-3]. In line with a trend toward advocating for the least restrictive environment in treatment settings, thereby also emphasizing patient autonomy, there is much focus on decreasing $\mathrm{CM}$ and, when one type of coercion is replaceable by a different one, to use the least invasive among CMs. Anyway, decreasing one measure sometimes is connected to increasing another which has been suggested, e.g., in the case of MR use versus psychopharmacological restraints [4].

The Danish Act on Coercive Measures in Psychiatry (Act 1160, 2015; Para 14) makes clear that "As means of mechanical restraints only belt, hand, and foot straps and gloves may be used. Fixation with mechanical restraints may be used only briefly and to the extent it is necessary to avert patients from either exposing themselves or others to imminent danger of harm to body or health, pursuing other patients or by similar means causing coarse inconvenience to other patients, or producing significant damage" [5]. By way of comparison, according to Para 17, psychopharmacological restraints in terms of coercive administration of emergency tranquilizers (CET; injection if necessary) can be used if considered necessary for "relieving the state of a very distressed patient". There continuously is a claim for proportionality between purpose and means and, as far possible, using the least intrusive remedy including, e.g., voluntary sedative drug administration [5]. It should be noted that, according to Danish law (See Ministerial Order on Use of Other Coercive Measures than Involuntary Admission, Para 26) and legal practice (see, e.g., the Danish Psychiatric Patients' Complaints Board, DPPCB, Yearbook 2014, p. 58), CET is considered less intrusive than MR use.

In harmony with current political appeals to substantially limit the use of MR in particular, total Danish use of MR now seems to decrease (from 6.165 in 2013 to 5.155 episodes in 2014) while there has been a rising utilization of CET from, e.g., 7414 episodes in 2013 to 7954 episodes in 2014 $[6,7]$. Remarkably, however, the number of complaints to the DPPCB about
CET substantially increased from 2013 to 2015 (47 per cent increase) whilst the number of complaints about MR use demonstrated a smaller increase with 18 percent more cases in 2015 [8]. In this regard, it is noteworthy that the amount of CET episodes found unlawful increased fivefold to more than 300 cases in 2015 while the number of MR episodes regarded against the law doubled and, by way of comparison, coercive psychopharmacologic treatment figures appear roughly unchanged.

It is explained by the DPPCB that the large increase of unlawful MR use from 2014 to 2015 may to a degree be caused by law changes confining the possibilities for longer term MR and that a large proportion of DPPCB decisions overruling MR appliance concern its duration [8]. There are only scant statistics available as to the number of cases found unlawful due to duration, though a general audit of published case law suggested cases about illegal long-term use of MR constitute a minority [9]. The development also could reflect a somewhat changed modus operandi or altered board composition. In any case, the tendency towards decreasing proportions of legitimate MR dates far back than the 2015 law revision.

As indicated above, MR in particular has attracted much political focus, possibly pressuring psychiatric staff to decrease its application, though raising the question about what is supposed to replace it. Concurrently CET use has risen but the DPPCB explains that increasing rates of rulings against CET are at least in part due to a change of practice. Contrary to the case with $M R$, however, it is worth noticing that this tightening of the board's practice cannot be explained by any change in law criteria for CET. Then DPPCB states that one single patient case contributed with $10 \%$ of the increase but if excluding this case there would still be a large increase. As far as concerns statistics from previous years, the typical amount of episodes arising from such 'outlier' cases remains unclear.

As it has been widely advocated that MR usage should be substantially decreased (and even halved), it is remarkable that the majority of MR episodes

Table 1. Complaint cases and DPPCB decisions about MR respectively CET use

\begin{tabular}{lccc}
\hline Year & $(2012)$ & 2013 & 2014 \\
\hline Number of legitimate MR episodes/total & $(260 / 305)$ & $247 / 317$ & 2015 \\
Percentage legitimate MR & $(85.2)$ & 77.9 & $249 / 342$ \\
Number of legitimate CET episodes /total & $(269 / 304)$ & $331 / 392$ & 75.7 \\
Percentage legitimate CET & $(88.5)$ & 84.4 & $293 / 435$ \\
\hline
\end{tabular}

Ref. Danish Psychiatric Complaint Board Yearbooks 2014 and 2015. Figures from 2012 are in brackets as they derive from aggregated data from the previously divided psychiatric complaint board system. 
complained about still are found lawful by the DPPCB and complying, e.g., with least intrusive remedy requirements according to law. While it presently does not seem realistic to entirely eradicate CM measures like CET or MR, the DPPCB plays an important role in maintaining psychiatric patients' legal rights by upholding a restrictive practice. Nonetheless, the figures suggest ongoing dynamics including a substantial growth in unauthorized CET practice amongst an increasing countrywide use of CET while the annual increase in MR and illegitimate MR procedures seem to partially level off. Further analysis is warranted on the use of CMs like MR and CET including clinical context and concordance with law requirements, to what extent substitution among CMs is taking place, and the mechanisms leading to increasing rates of $\mathrm{CM}$ episodes found unlawful.

\section{REFERENCES}

[1] Keski-Valkama A, Sailas E, Eronen M, Koivisto AM, Lonnqvist J, Kaltiala-Heino R. Who are the restrained and secluded patients: a 15-year nationwide study. Social psychiatry and psychiatric epidemiology. 2010;45(11):1087-93.

[2] Steinert T, Lepping P, Bernhardsgrutter R, Conca A, Hatling T, Janssen W, et al. Incidence of seclusion and restraint in psychiatric hospitals: a literature review and survey of international trends. SocPsychiatry PsychiatrEpidemiol. 2010;45(9):889-97.

[3] Gaskin CJ, Elsom SJ, Happell B. Interventions for reducing the use of seclusion in psychiatric facilities: review of the literature. The British journal of psychiatry : the journal of mental science. 2007;191:298-303.

[4] Georgieva I, Mulder CL, Noorthoorn E. Reducing seclusion through involuntary medication: a randomized clinical trial. Psychiatry research. 2013;205(1-2):48-53.

[5] Birkeland S, Gildberg FA. Mental Health Nursing, Mechanical Restraint Measures and Patients' Legal Rights. Open Nurs J. 2016;10:8-14.
[6] Opgørelse over anvendelse af tvang i psykiatrien 2001-2013. (2014). Statens Serum Institut, Sundhedsdokumentation, Sektor for National Sundhedsdokumentation og Forskning. [Udarbejdet af Ministeriet for Sundhed og Forebyggelse den 6. maj 2014..

[7] Sundhedsstyrelsen. Monitorering af tvang i psykiatrien 2014. Danish Health and Medicines Authority [Sundhedsstyrelsen], 2015 May 2015.

[8] Yearbooks 2007-2015 of the Danish Psychiatric Patient Complaint Board (Årsberetninger for de Psykiatriske Patientklagenævn 2007-2015). Copenhagen: The Danish Psychiatric Patients Complaints Board (Det Psykiatriske Patientklagenævn), Patientklagenævn).

[9] Birkeland S. Threats and violence in the lead-up to psychiatric mechanical restraint - a Danish complaints audit. The Journal of Forensic Psychiatry \& Psychology 21 Jun 2017: 1-7. https://doi.org/10.1080/14789949.2017.1342271. 